\title{
AHLUSSUNNAH WAL JAMAAH \\ DALAM TINJAUAN HADITS IFTIROQ
}

Ade Wahidin

Dosen Tetap Prodi IAT STAI Al-Hidayah Bogor

\begin{abstract}
Abstraks
Perpecahan yang terjadi pada internal kaum muslimin, secara teoritis telah ditetapkan oleh Nabi dalam sabda-sabdanya.Sehingga tidak diragukan lagi validitas dan keabsahan masalah ini.Dalam sabdanya tersebut, disebutkan satu golongan yang selamat dan 72 tidak selamat.Kemudian disebutkan tentang karakteristik golongan yang selamat tersebut.

Menariknya, Nabi hanya menjelaskan karakteristik golongan yang selamat, hal ini supaya umat Islam mudah mengenali dan mempelajarinya hingga bisa menginternalisasikannya dalam dirinya supaya menjadi bagian darinya.Golongan yang selamat itu adalah Ahlussunnah Waljamaah.
\end{abstract}

Keyword: Ahlussunnah, Hadits Iftirāq

\section{A. PENDAHULUAN}

Secara fitrah semua manusia menginginkan kedamaian, ketentraman dan kebahagiaan.Salah satu sarana untuk mencapai tujuan dan keinginan tersebut adalah dengan persatuan.Akan tetapi untuk mewujudkan persatuan tidaklah semudah membalikkan telapak tangan.Karena pada tataran realitasnya banyak faktor yang menghambat terwujudnya persatuan tersebut.mulai dari yang sepele sampai kepada faktor yang sangat fundamental dalam kehidupan beragama manusia.

Pada dasarnya, agama Islam sangat menganjurkan terwujudnya persatuan dan kedamaian dalam tatanan kehidupan manusia secara umum dan pada tataran pemeluk-pemeluknya secara khusus. Hal ini sebagaimana yang tersirat dan tersurat dalam teks-teks al-Quran dan Hadits Rasululloh khususnya yang bersinggungan langsung dengan persatuan kaum muslimin, bahkan tidak tanggung-tanggung teks-teks 
tersebut mewajibkan terwujudnya persatuan di antara kaum muslimin. Diantara teks-teks tersebut adalah:

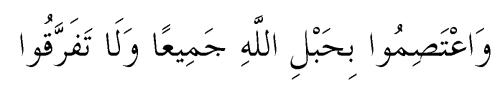

"Berpegang teguhlah kalian semua dengan tali Allah dan janganlah kalian berpecah belah" (QS. Ali Imran: 103)

Ayat tersebut secara eksplisit memerintahkan persatuan dan melarang perpecahan.Bahkan dalam sebuah hadits juga disebutkan yang semakna dengan ayat tersebut. Rasulullah bersabda,

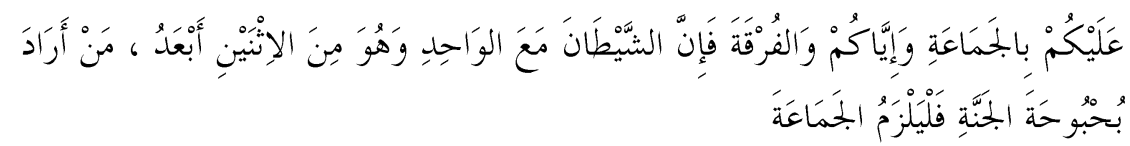

Hendaknya kalian berpegang teguh dengan jamaah dan hindari perpecahan. Karena sesungguhnya setan itu bersama dengan seorang yang menyendiri dan ia akan jauh dengan orang yang berdua. Barangsiapa yang ingin kenikmatan surge maka hendaknya berpegang teguh pada jamaah.(HR. Tirmidzi). ${ }^{177}$

Di sisi lain sudah menjadi sunnatullah fi al-kaun (ketetapan Allah di alam semesta) bahwa perselisihan dan perpecahan pasti terjadi di kalangan manusia. ${ }^{178}$ Bahkan perselisihan tersebut tidak hanya terjadi

${ }^{177}$ Māzin ibn 'Abd al-Karīm al-Furaih, al-Rāid Durūs F̄̄ al-Tarbiyah Wa alDa'wah, Dar al-Andalus al-Khadhrā: Jeddah, Juz: 2, hlm. 249-250.

${ }^{178}$ Dalam al-Qur’an, Allah menyebutkan tentang hal ini dalam beberapa ayat di antaranya sebagai berikut:

Pertama: Surat Yunus ayat 19.

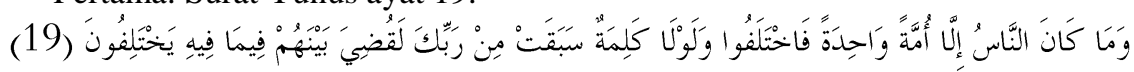

"Manusia dahulunya hanyalah satu umat, kemudian mereka berselisih.kalau tidaklah karena suatu ketetapan yang telah ada dari Tuhanmu dahulu, pastilah telah diberi keputusan di antara mereka, tentang apa yang mereka perselisihkan itu.”

Berkaitan dengan ayat ini, Imam Ibn Katsīr berkata:

$$
\begin{aligned}
& \text { ثم أخبر تعالى أن هذا الشرك حادث في الناس، كائن بعد أن لم يكن، وأن الناس كلهم كانوا }
\end{aligned}
$$

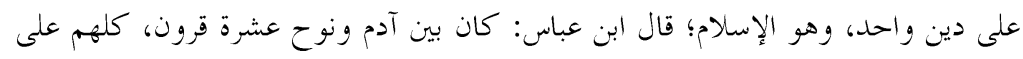

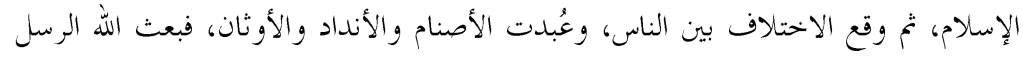

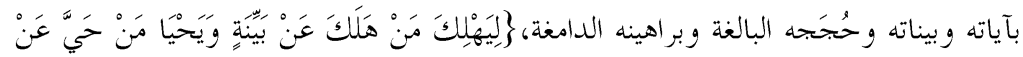

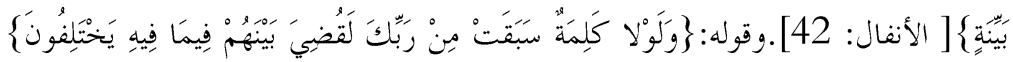


pada manusia yang tidak beriman kepada Allah dan Rasul-Nya, tetapi juga akan terjadi pada orang-orang yang sudah mengaku bahwa Allah

$$
\begin{aligned}
& \text { أي: لولا ما تقدم من الله تعالى أنه لا يعذب أحدا إلا بعد قيام الحجة عليه؛ وأنه قد أجل الحلقق }
\end{aligned}
$$

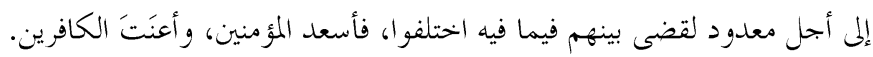

Kemudian Allah menginformasikan bahwa, syirik ini adalah perkara baru yang menimpa umat manusia setelah sebelumnya mereka berada di atas agama yang satu yaitu Islam.Ibn 'Abbās berkata, "Jarak masa antara Nabi Adam dan Nabi Nuh adalah sepuluh kurun (1000 tahun), semuanya berada di atas agama Islam.Kemudian manusia berselisih dan terpecah, berhala dan patung mulai disembah.Sehingga Allah mengutus para Nabi dan Rasul ayat-ayat-Nya dan argumentasi yang kuat. "Agar orang yang binasa itu binasanya dengan keterangan yang nyata dan agar orang yang hidup itu hidupnya dengan keterangan yang nyata. " (QS. Al-Anfal: 42). Firman Allah "Walau La kalimatun..." yaitu, Sebagaimana yang telah Allah tetapkan untuk tidak menyiksa seorang hamba melainkan setelah tegaknya dalil kepadanya, dan sesungguhnya Allah telah memberikan ajalnya masing-masing untuk makhluk-Nya, maka pasti Allah akan mengadili perselihan yang terjadi antara mereka, sehingga orang-orang beriman akan bahagia dan orang-orang kafir akan sengsara." Abū al-Fidā Ismā'̄il ibn 'Umar ibn Katsīr al-Qurasyī alDimasyqī, Tafsīr al-Qur'ān al-'Až̄im, Tahqīq: Sāmī ibn Muhammad Salāmah, Dar Thaibah, Juz: 4, hlm. 257.

Kedua: Surat Hud ayat 118.

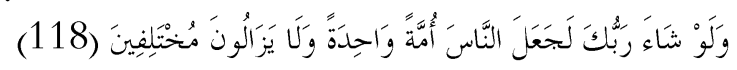

"Jikalau Tuhanmu menghendaki, tentu Dia menjadikan manusia umat yang satu, tetapi mereka senantiasa berselisih pendapat."

Berkaitan dengan ayat ini al-Sa'dī berkata,

$$
\begin{aligned}
& \text { يخبر تعالى أنه لو شاء لجعل الناس كلهم أمة واحدة على الدين الإسلامي، فإن مشيئته غير }
\end{aligned}
$$

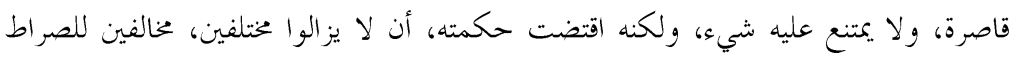

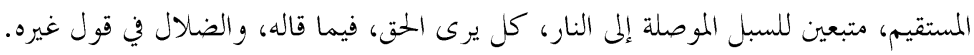

Allah menginformasikan bahwasannya, seandainya Allah berkehendak niscaya Dia jadikan seluruh manusia berada di atas agama yang satu, yaitu Islam.Karena sesungguhnya kehendaknya tidak terbatas dan tidak ada sesuatupun yang mampu mencegahnya.Akan tetapi perpecahan ini terjadi tentu berdasarkan sifat hikmah Allah Ta'ala.Mereka menyelisihi jalan yang lurus dan mengikuti jalan-jalan yang menuju neraka. Masing-masing melihat kebenaran ada padanya berdasarkan klaimnya, sedangkan kesesatan ada pada yang lain. 'Abd al-Rahmān ibn Nāshir al-Sa'dī, Taisīr al-Karīm al-Raḩmān Fì Tafsīr Kalām al-Mannān, Tahquīq: 'Abd al-Rahmān ibn Mu'allā al-Luwaihiqu, Muassasah alRisalah, hlm. 392. 
adalah Tuhannya dan Muhammad adalah utusan-Nya. Perselisihan antara kaum muslimin ini ada yang sifatnya fundamental yaitu perpecahan yang menyebabkan pelakunya dapat terjerumus ke dalam kekufuran.Ada juga yang sifatnya tidak fundamental yaitu perpecahan yang menyebabkan pelakunya tidak sampai keluar dari framework keislaman.Dalam perselisihan dan perpecahan yang masih dalam bingkai Islam tersebut, terdapat satu golongan yang benar yang disebut dengan Ahlussunnah Waljamaah dan 72 golongan lainnya yang dianggap sesat sebagaimana yang dikabarkan oleh Nabi Muhammaddalam beberapa haditsnya, diantaranya adalah:

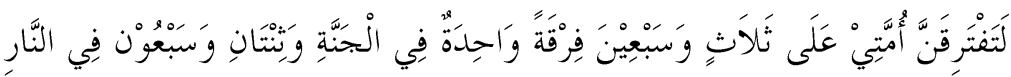

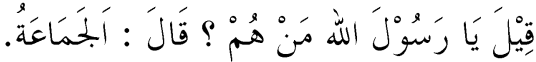

"Sesungguhnya umatku berpecah-belah menjadi 73 golongan. Satu golongan di dalam surga dan 72 golongan di dalam neraka. Ditanyakan kepada beliau: "Siapakah mereka (yang satu golongan) itu ya Rosululloh ? Beliau menjawab: Al Jama`ah" (H.R. Ibnu Majah No. 3992)

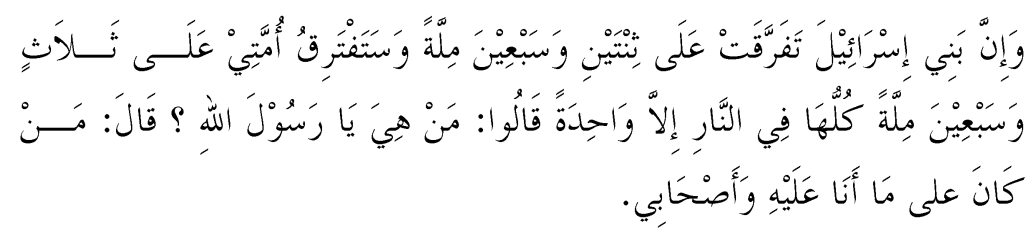

"Sesungguhnya Bani Israil berpecah-belah menjadi 72 kelompok keagamaan, dan umatku akan berpecah-belah menjadi 73 kelompok keagamaan. Seluruhnya berada di api neraka, kecuali satu kelompok. Mereka (para sahabat) bertanya: Siapakah satu kelompok itu ya Rosululloh? Beliau menjawab: "Mereka yang mengikuti jejakku dan jejak sahabat-sahabatku" (H.R. al-Tarmidzi No. 2643)

Hadits-hadits ini biasa disebut dengan hadits Iftirāq atau furqah (perpecahan), maksudnya adalah hadits yang menjelaskan tentang terjadinya perpecahan dikalangan umat Nabi Muhammad. Dan bahwa perpecahan yang terjadi dikalangan kaum muslimin adalah realitas yang tidak bisa dipungkiri.

Walaupun demikian, Nabi Muhammad memberikan solusi untuk terhindar dari golongan-golongan sesat yang dapat memecah belah umat, dengan cara berpegang teguh pada golongan Ahlussunnah wal jama'ah. 
Karena hanya dengan berpegang teguh pada al-jamaah dan mengikuti jejak Nabi Muhammad dan para sahabatnya umat Islam akan selamat dari api neraka. Bahkan diyakini, bahwa ahlussunnah adalah sarana dan wadah untuk mempersatukan umat Islam.

Semakin jauh manusia dari zaman kenabian, semakin jauh pula mereka dari kebenaran.Apalagi bila dibandingkan dengan zaman sekarang.Hal ini didasarkan pada memudarnya kecintaan dan antusiasme menuntut ilmu syar'i dan pengamalannya dalam jiwa-jiwa kaum muslimin di satu sisi. Dan merebaknya fitnah syahwat dan syubhat secara masif di sisi yang lain. Sehingga disadari atau tidak, sedikit sekali kaum muslimin yang memahami hakikat Ahlussunnah wal jama'ah.

Oleh karena itu, wajib bagi setiap muslim untuk memahami konsepsi Ahlussunnah yang benar. Karena saat ini, pada tataran realitas telah didapatkan pengakuan-pengakuan dari kelompok tertentu yang mengklaim dirinya sebagai Ahlussunnah.Ironisnya, terkadang ada kelompok yang mengkalaim dirinya sebagai satu-satunya Ahlussunnah Waljamaah, sedangkan yang lainnya adalah bukan Ahlussunnah Waljamaah.Padahal setelah ditelusuri, kelompok tersebut manhajnya (metodologi beragama) masih jauh dari Ahlussunnah Waljamaah.

\section{B. AHLUSSUNNAH WALJAMAAH DALAM TINJAUAN HADITS IFTIROQ}

\section{Hadits-hadits Iftirāq}

Jika ditelusuri secara mendalam dan komprehensif, maka ada beberapa redaksi hadits yang berbicara tentang Iftirāq, terutama yang sahihnya.Berikut ini penjelasannya:

a. Riwayat Sahabat Mu'awiyah ibn Abu Sufyan(HR. Abu Dawud)

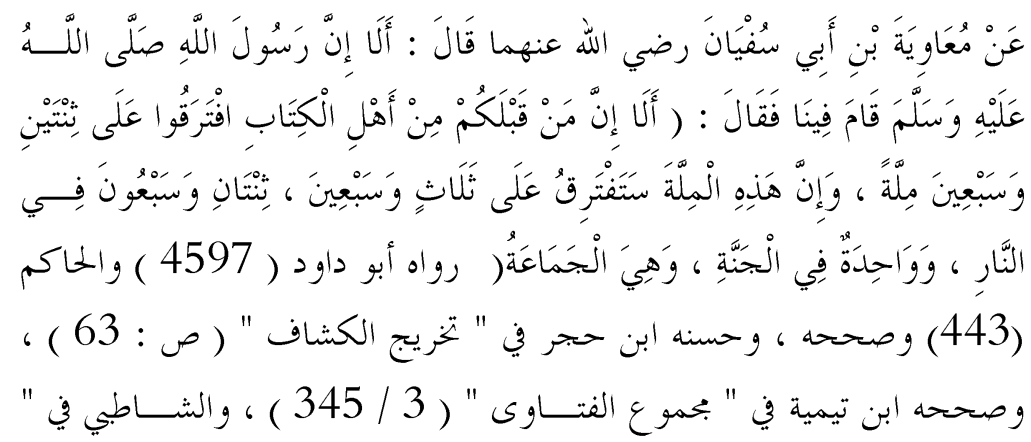


melakukannya, dan sungguh Bani Israil itu telah terpecah menjadi tujuh puluh dua agama (aliran), dan umatku akan terpecah menjadi tujuh puluh tiga agama, semuanya masuk neraka kecuali satu agama." Para sahabat bertanya: agama apa itu wahai Rasulullah?, Beliau menjawab: "Apa yang aku dan para sahabatku berpijak di atasnya." (HR. AtTirmidzi, berkata Abu 'Isa: hadits ini hasan gharib) ${ }^{180}$

c. Riwayat Sahabat 'Auf ibn Malik (HR. Ibn Majah)

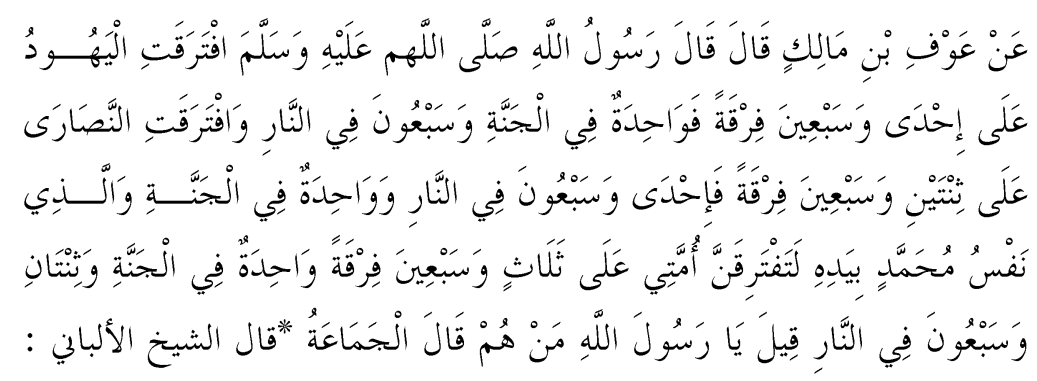

صحيح

"Dari Auf bin Malik ia berkata : Telah bersabda Rasulullah Shallallahu 'Alaihi wa Sallam : Sesungguhnya umatku akan terpecah menjadi 73 (tujuh puluh tiga) golongan, satu golongan masuk surga, dan tujuh puluh dua golongan masuk neraka". Beliau ditanya : "Ya Rasulullah, Siapakah satu golongan itu ?". Beliau menjawab ; "Al-Jama'ah". (HR. Ibn Majah, disahihkan al-Albani) ${ }^{181}$

d. Riwayat Sahabat Anas ibn Malik (HR. Ibn Majah)

$$
\begin{aligned}
& \text { عن أنس ابن مالك قال قال رسول الله صلى الله عليه و سلم( إن بي إســـائيل }
\end{aligned}
$$

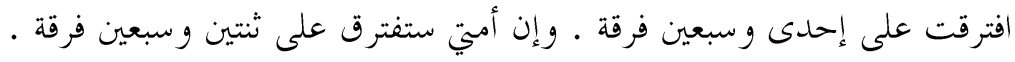

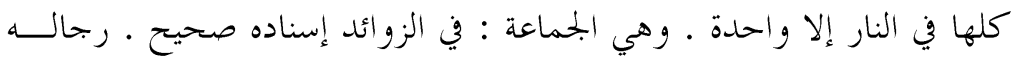

$$
\begin{aligned}
& \text { ثقات) قال الشيخ الألباني : صحيح }
\end{aligned}
$$

${ }^{180} \mathrm{http}: / / \mathrm{www} . v i s i m u s l i m . n e t / 2014 / 09 /$ memahami-hadits-terbaginya-kaummuslimin-menjadi-73-golongan.html, diakses pada hari kamis, 18 Mei 2017, pukul 08.45 WIB.

${ }^{181}$ http://salafy-ums.blogspot.co.id/2011/08/kedudukan-hadits-tujuh-puluhdua.html, diakses pada hari kamis, 18 Mei 2017, pukul 08.45 WIB. 
Dari Anas ibn Malik berkata, Rasulullah Shallallahu 'Alaihi wa Sallam bersabda, "Sesungguhnya bani Israil terpecah menjadi 71 golongan, dan sesungguhnya umatku terpecah menjadi 72 golongan, semuanya di neraka kecuali satu yaitu al-Jama'ah.” (HR. Ibn Majah, dalam al-Zawaaid sanadnya sahih dan para perawinya terpercaya, alAlbani berkata: sahih)

e. Riwayat Sahabat Abu Hurairah(HR. Abu Dawud)

$$
\begin{aligned}
& \text { عن أبي هريرة رضي الله عنه، قال: قال رسول الله صلى الله عليه وسلم: "افترقَت }
\end{aligned}
$$

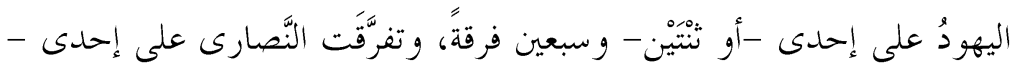

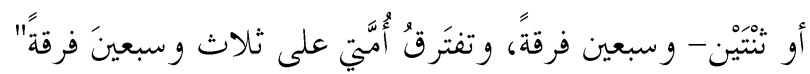

"Dari Abu Hurairah ia berkata : "Telah bersabda Rasulullah SAW. Kaum Yahudi telah terpecah menjadi 71 (tujuh puluh satu) golongan atau 72 (tujuh puluh dua) golongan dan Kaum Nashrani telah terpecah menjadi 71 (tujuh puluh satu) golongan atau 72 (tujuh puluh dua) golongan dan ummatku akan terpecah menjadi 73 (tujuh puluh tiga) golongan" (HR. Abu Dawud). ${ }^{182}$

Dari penjelasan hadits-hadits iftirāq tersebut, dapat disimpulkan bahwa hadits-hadits yang berbicara perpecahan umat itu sanad atau jalur periwayatannya sahih, terutama yang menyebut 73 golongan, satu di surga sedangkan yang lainnya di neraka. ${ }^{183}$

\section{Makna Hadits Iftirāq}

Adapun terkait makna hadits-hadits iftiraq ini, maka berikut penjelasan singkatnya yang dikutip dari beberapa ulama.

Al-Mubarakfuri menjelaskan dalam kitabnya syarah Tirmidzi bahwa sabda Nabi, "Umatku terpecah menjadi 73 golongan" maksud

${ }^{182}$ Salmān al-'Audah, http://www.ahlalhdeeth.com/vb/showthread.php?t=2710, diakses pada hari Rabu, 17 Mei 2017, pukul 16.30.

${ }^{183}$ Karena memang ada juga redaksi lainnya dengan menyebut 72 dan 71 , tetapi sanad hadits yang menyebut 73 golongan jauh lebih sahih.Lihat http://salafyums.blogspot.co.id/2011/08/kedudukan-hadits-tujuh-puluh-dua.html, diakses pada hari kamis, 18 Mei 2017, pukul 08.45 WIB. 
umatku di sini adalah umat ijābah yaitu umat Islam.Dalam hadits dari jalur Abdullah ibn 'Amr juga disebutkan bahwa semua golongan tersebut akan masuk neraka kecuali satu.Hal ini menunjukkan kemukjizatan Nabi yang menginformasikan kabar gaib yang faktual.

Al-'Alqami mengatakan bahwa guru kami Imam Abu Manshur al-Tamimi berkata terkait dengan makna hadits ini.

"Para ulama tentunya memahami bahwa maksud tercelanya perpecahan umat yang disabdakan Nabi ini bukanlah umat islam yang berselisih pendapat dalam masalah fikih atau masalah halal dan haram.Akan tetapi maksudnya siapa saja yang menyelisihi pengusung kebenaran dalam pokok-pokok akidah, takdir baik dan buruk, syaratsyarat kenabian, membela para sahabat dan lain semacamnya.Karena perselisihan pendapat dalam masalah ini, bisa mengantarkan kepada kekeufuran. Berbeda dengan perselisihan model pertama yang apabila beda pendapat maka tidak ada istilah mengkafirkan dan menfasikkan lawannya. Maka inilah makna perpecahan yang dimaksud nabi.Fenomena ini telah terjadi pada akhir zaman para sahabat.Seperti konsep takdir yang dikonsepkan oleh Ma'bad al-Juhani dan para pengikutnya.Kemudian perpecahan tersebut semakin melebar dan massif hingga jumlah golongannya mencapai 72 golongan.Adapun yang ke 73 mereka adalah Ahlussunnah Waljamaah, mereka adalah golongan yang selamat. "184

Maksud sabda Nabi "umatku" adalah bisa bermakna umat dakwah.Maka mencakup seluruh agama dan aliran yang bukan Islam yang terpecah menjadi 73 golongan.Atau maksudnya umat ijabah.Akan tetapi maksud golongan 73 ini seluruhnya masih dalam lingkaran Islam. ${ }^{185}$

Maksud dari hadits ini adalah bahwa siapa saja yang mengikuti cara beragama nabi dan para sahabatnya maka merekalah yang disebut dengan golongan selamat. Adapun yang menyelisishi Nabi walaupun

${ }^{184}$ Muhammad 'Abdurrahmān ibn 'Abdurrahīm al-Mubārakfūrī Abū al-'Alā, Tuhfat al-Ahwwadzī Bisyarh Jāmì' al-Tirmidzī, Dar al-Kutub al-'Ilmiyah: Beirut, juz: 7, hlm. 334.

${ }^{185}$ Al-Qādhī Nāshir al-Dīn 'Abdullāh ibn 'Umar al-Baidhāwī, Tuhfat al-Abrār Syarh Mashābih al-Sunnah, Tahqīq: Tim Khusus diketuai Nuruddin Thalib, Wazaratul Awqaf Wa al-Syuun al-Islamiyah: Kuwait, 2012, Juz: 1, hlm. 140. 
sedikit maka tidaklah disebut dengan golongan yang selamat.Di samping itu, hadits ini tidaklah menunjukkan bawa golongan-golongan yang menyimpang dari garis Ahlussunnah tersebut adalah kafir. Karena tidaklah setiap yang masuk neraka itu kafir, akan tetapi golongan ini antara Ahlussunnah dan kekufuran. Oleh karena itu, Ahlussunnah tidak mengkafirkan semua golongan tersebut.Kecuali ada golongan yang secara prinsipil memiliki keyakinan kufur.Maka saat itu mereka telah murtad dari Islam.Seperti golongan-golongan kebatinan. ${ }^{186}$

Jadi, makna perpecahan umat disini adalah perpecahan umat Islam dalam masalah akidah dan prinsip-prinsip dalam Islam bukan perbedaan pendapat dalam bidang fikih.

\section{Analisis Hakikat Ahlussunnah Waljamaah}

Dalam hadits iftirāq tersebut, Rasulullah telah menegaskan tentang realitas perpecahan yang akan menimpa umatnya di masa yang akan datang. Bahwa umatnya akan terpecah menjadi 73 golongan keagamaan, dimana hanya satu yang akan selamat. Sebagai generasi yang haus akan ilmu, para sahabat tidak tinggal diam dalam menyikapi hadits tersebut. Lantas mereka bertanya kepada Rasulullah tentang siapakah golongan yang selamat tersebut.Kemudian Rasulullah menjawab mereka adalah al-Jama'ah. Dalam redaksi yang lain mereka adalah siapa saja yang mengikuti jejakku dan jejak para sahabatku.

Sabda Rasulullah "aljamaah dan siapa saja mengikuti jejakku dan jejak para sahabatku"membutuhkan penjabaran lebih lanjut tentang maksud daripada hadits tersebut .Maka dalam hal ini, para ulama telah meletakkan kaidah-kaidah umum yang ideal tentang manhaj ahlussunnah waljamaah. Dimana ketika ada seseorang atau sebuah kelompok berpegang teguh pada kaidah-kaidah tersebut maka orang atau kelompok tersebut berhak menyandang predikat sebagai Ahlussunnah Waljamaah. Berikut ini konsepsi ahlussunnah waljamaah yang ideal menurut para ulama:

${ }^{186}$ Abu Hamzah al-Syami,

http://www.ahlalhdeeth.com/vb/showthread.php?t=21489, diakses pada hari Jum'at, 19 Mei 2017 pukul 09.05 WIB. 


\section{a. Definisi Ahlussunnah Wal Jamaah}

Kata ahlusunnah waljamaah berasal dari bahasa arab yang terdiri dari tiga suku kata; $A h l$ (keluarga atau pengikut), ${ }^{187}$ as-Sunnah (metode atau perilaku), ${ }^{188}$ dan al-Jamaah (kelompok). ${ }^{189}$

Secara terminology syar'I definisi ahlusunnah dapat diuraikan ke dalam dua bagian; pertama adalah Sunnah dan kedua adalah Jamaah.

Pertama: arti Sunnah.Sunnah itu sendiri mempunyai banyak arti, yang hampir semuanya merupakan lingkaran-lingkaran yang terkadang berbeda-beda besarnya,yang masing-masing berada di dalam yang lainnya. Arti-arti itu dari arti yang terluas sampai arti yang tersempit sebagai berikut: ${ }^{190}$

1) Mencakup seluruh isi agama Islam, Al-Qur'an dan Hadits, mencakupseluruh keadaan Rosululloh dari segi ilmiahdan amaliah.

Berkata Syaikhul Islam Ibnu Taimiyyah -rohimahulloh-:

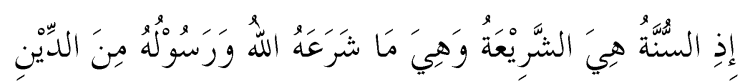

"Sunnah itu adalah syari'ah yaitu apa-apa yang disyari'ahkan oleh Alloh dan Rosul-Nyadari agama". ${ }^{191}$

2) Sunnah dalam arti lawannya bid'ah. Arti ini pun bisa mencakup seluruhma'na, sebab bid'ah adalah lawannya Al Qur'an dan Al Hadits. Bersabda Rosulullohdalam musnad Imam Ahmad (4/105) dihasankan oleh as-Suyuthi:

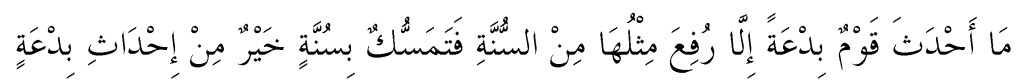

"Tidak ada satu bid'ah pun yang dilakukan oleh suatu kaum, kecuali dicabut satu sunnah tandingannya. Maka, berpegang teguh dengan sunnah lebih baik daripada membuat bid ah "

3) Sunnah dalam arti hadits Rasulullah.

4) Sunnah dalam arti ushuluddin yaitu dasar-dasar agama dan aqidah.

187 A.W. Munawwir, Kamus al-Munawwir Arab-Indonesia Terlengkap, Surabaya: Pustaka Progressif, 1997 M, Hlm. 46.

${ }^{188}$ Ibid., lihat makna lainnya Hlm. 669.

${ }^{189}$ Ibid., Hlm. 209.

${ }^{190}$ Team Ilmiah Eldasi, Ahlusunnah Waljamaah Metode Beragama Para Salaful Ummah,Pustaka al-Faruq. Hlm. 20.

${ }^{191}$ Ibn Taimiyah, Majmu'at al-Fatawa, (4/436) 
Ibnu Rojab -rohimahulloh- berkata:

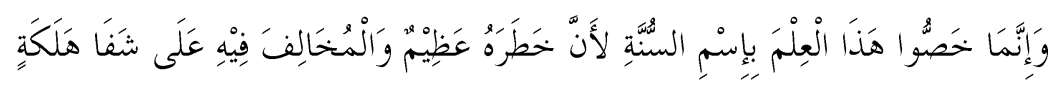

"Banyak dari ulama mengkhususkan ilmu aqidah dengan nama sunnah, karena urgensi aqidah adalah agung yang mana setiap penyimpangnya berada dalam bahaya besar".

Banyak pula buku-buku salafus soleh yang berjudul "As sunnah" yangberisi ilmu-ilmu aqidah seperti As-Sunnah yang ditulis oleh $A b u$ BakrAl-Atsram(W. $272 \mathrm{H}$ ), Kitabussunnah yang ditulis oleh IbnuAbi 'Asim (W. 287 H), As Sunnah yang ditulis olehMuhamad Bin Nasr Al Mirwazi(W. 294 H), Sorihus sunnah yang ditulis oleh Ja'far At Thobari (W. 310 H) dan lain-lain ${ }^{192}$.

5) Sunnah dalam arti nafilah atau mustahabbah yang arti-nya amal-amal yang kalau dikerjakan diberi pahala dan kalau ditinggalkan tidak mengakibatkan dosa. ${ }^{193}$

Kedua: al-Jama'ah.

Al-Jamaah adalah sekelompok orang yang berkumpul dan bersatu diatas kebenaran yang berdasarkan al-Qur'an dan Hadits, dan mereka adalah para sahabat dan orang-orang yang setia mengikuti mereka walaupun jumlah mereka sedikit. Hal ini sebagaimana yang dikatakan oleh ibn Mas'ud:

$$
\text { "الجماعة ما وافق الحق وإن كنت وحدك فإنك أنت الجماعة حينئذ" }
$$

"Jamaah adalah siapa saja yang sesuai dengan kebenaran walaupun engkau seorang diri, (jika demikian) maka engkau adalah jamaah ketika itu". 194

Dengan demikian arti jama'ah dalam istilah berarti "persatuan di atas sunnah" atau "orang orang yang bersatu di atas sunnah". Demikianlah keadaan sahabat dalam kehidupan mereka, dari itu jama'ah yang berarti "sahabat" adalah penafsiran yang benar. Dengan berpegang pada arti-arti di atas, maka tafsiran Al-Imam Bukhori serta ulama salaf lainnya dari pengikut - pengikut mereka, bahwa jama`ah

${ }^{192}$ Team Ilmiah Eldasi, Ahlusunnah Waljamaah Metode Beragama Para Salaful Ummah,Pustaka al-Faruq. Hlm. 21.

${ }^{193}$ Lihat kitab-kitab Ushul Fikih, seperti al-Waraqāt karya Imam al-Juwaini.

${ }^{194}$ Shālih al-Fauzān, Syarh al-'Aqīdah al-Wāsithiah, Kairo: Dār al-Aqīdah 1426 H/2005 M, Hlm. 57-58. 
adalah "kaum ulama sunnah" termasuk dalam tafsiran-tafsiran yang benar. Arti jama`ah secara syari’at juga "jama 'atul mus limin (Jama`ah Ahlus Sunnah) yang dipimpin oleh seorang imam". ${ }^{195}$

Setelah diketahui definisi Sunnah dan Jamaah baik itu secara etimologi maupun terminologi.Setidaknya sudah tergambar makna ataupun definisi yang sebenarnya tentang Ahlussunnah waljamaah. Maka sesuai namanya, komunitas ini memiliki dua karakter utama: kesesuaiannya dengan sunnah dan loyalitasnya terhadap jama'ah, yaitu para sahabat Nabi dan generasi-generasi yang mengikuti jejak mereka dengan baik. ${ }^{196}$ Dan untuk lebih jelasnya, Berikut ini definisi Ahlussunnah wal jamaah yang jāmi' (mencakup semua unsurunsurnya) dan māni' (mengeluarkan semua yang bukan unsurunsurnya):

“Golongan yang berpegang teguh dengan Al-Qur'an dan sunnah serta pemahaman dan penerapan para sahabat dalam memahami dan mengamalkan Islam ".

"Termasuk dalam golongan mereka para sahabat rosul, tabi in, tabi'it tabi in, kaum ulama sunnah dan para pengikut mereka (dari semua lapisan umat) sampai hari kiamat".

"Ahlussunnah adalah seluruh kaum muslimin, setelah dikecualikan Ahlul Bid'ah dan Ahlul Furqoh".

Definisi ini berdasarkan suatu ketetapan di dalam Islam bahwa ummat ini terbagi dua golongan yaitu golongan yang berada di atas sunnah wal jama'ah dan golongan yang berada di jalan bid'ah. Definisi ahlul bid'ah adalah mereka yang berpegang pada salah satu dasar bid'ah atau orang yang dilumuri bid'ah dalam kehidupannya, maka semua kaum muslimin yang tidak demikian adalah Ahlussunnah walaupun dia seorang yang jahil (bodoh). Di waktu yang sama, sekedar terkadang terjatuh pada suatu bid'ah tidak menjadikan seseorang itu sebagai ahlul bid'ah. ${ }^{197}$

${ }^{195}$ Team Ilmiah Eldasi, Ahlusunnah Waljamaah Metode Beragama Para Salaful Ummah,Pustaka al-Faruq. Hlm. 22.

${ }^{196}$ Abas Manshur Tamam, Ahlussunnah Waljamaah, Agenda Wihdatul Ummah (sebuah makalah yang disampaikan di Hotel Aston, 11 Desember 2012).Hlm. 2.

${ }^{197}$ Team Ilmiah Eldasi, Ahlusunnah Waljamaah Metode Beragama Para Salaful Ummah,Pustaka al-Faruq. HIm. 23-24. 
Demikianlah definisi Ahlussunnah waljamaah yang benar, semoga setiap muslim dapat mengukur dirinya dengan definisi diatas. Tetapi masih ada perkara lain yang sama pentingnya untuk diketahui dan difahami oleh setiap muslim. Perkara itu adalah tentang Mabādi (prinsip-prinsip dasar) yang dimilki ahlussunnah waljamaah.Karena seseorang dapat dikatakan sebagai Ahlusunnah waljamaah atau bukan tergantung pada prinsip-prinsip tersebut.

1) Prinsip-prinsip Dasar Ahlussunnah Waljamaah

Para ulama telah menetapkan prinsip-prinsip dasar Ahlussunnah Waljamaah. Hal ini berdasarkan Istiqra ${ }^{\prime}$ (penelitian) yang mereka lakukan terhadap teks-teks al-Quran dan Hadits Rasulullah $\square$ Berikut ini sebagian besar prinsip-prinsip dasar Ahlussunnah wal-Jamaah yang pada dasarnya adalah prinsip-prinsip yang diusung oleh agama Islam yang murni, yaitu Islam yang sebagaimana Allah turunkan kepada Nabi Muhammad:

a) Sumber agama Islam dengan segala seginya adalah wahyu Alloh dalam bentuk Al-Qur'an dan Hadits yang shohih. ${ }^{198}$

Dalil prinsip ini adalah Firman Alloh:

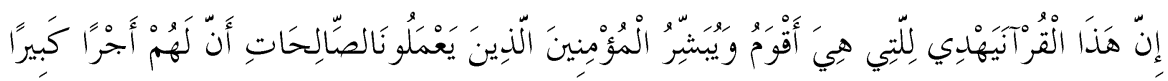

"Sesungguhnya al-Qur'an ini memberikan petunjuk kepada (jalan) yang amat lurus dan memberi khabar gembira kepada orang-orang Mu'min yang mengerja-kan amal saleh bahwa bagi mereka ada pahala yang besar.’\{QS. Al Isro` [17]: 9\}

Alloh Subhanahu wa Ta ala berfirman:

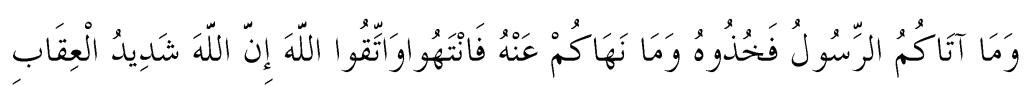

"Apa yang diberikan Rosul kepada kalian maka terimalah dia. Dan apa yang dilarangnya bagi kalian maka tinggalkanlah dan bertaqwalah kepadaAlloh. Sesungguhnya Alloh sangat keras hukumanNya." \{QS.Al Hasyr [59]: 7\}

Rosululloh Shallallohu `alaihi wa sallam bersabda:

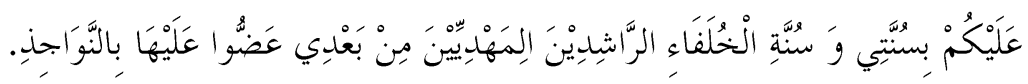

${ }^{198}$ Ibid., Hlm. 25-26. 
"Hendaklah kalian berpegang teguh pada sunnahku dan sunnah para khalifah Rasyidin (yang terarahkan) dan mendapat petunjuk setelahku. Gigitlah hal ter-sebut dengan gigi geraham".

b) Ijma` sahabat adalah hujjah syar'iyyah ${ }^{199}$.

Ini berarti bahwa ketika sahabat telah berijma' pada suatu masalah dalam agama, maka ijma' itu harus diikuti. Siapa yang melanggarnya akan ber-dosa dan sesat. Ijma`Sahabat pada Ahlussunnah adalah ma'sum, walaupun perorangan mereka tidaklah ma'sum. Ketika keyakinan mereka pada suatu masalah terbagi atas lebih dari satu, maka kita harus mengikuti salah satunya dan tidak boleh menentukan keyakinan lainnya.

Alloh Subhanahu wa Ta'ala berfirman:

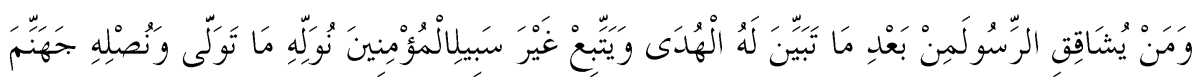

وَسَاَتَتْمَصِيرًا

"Dan barangsiapa yang menentang rosul sesudah jelas kebenaran baginyaserta mengikuti jalan yang bukan jalan orang-orang mu'min, Kami biarkan ia leluasa ter-hadap kesesatan yang telah dikuasainya itu dan Kami masukkania ke dalam Jahannam dan Jahannam itu seburuk-buruknya tempat kembali". \{QS. An Nisa' [4]: 115\}

Rosululloh Shallallohu `alaihi wa sallam bersabda:

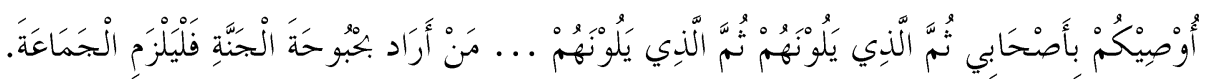

"Aku wasiatkan kalian (mengikuti) para sahabatku, ke-mudian orang-orang sesudah mereka, kemudian orang-orang kemudiannya. Barangsiapa yangmenghendaki keluasan jannah, maka berpegang teguhlah dengan jama`ah".

c) Pemahaman Al-Qur'an dan Hadits harus sesuai dengan pemahaman sahabat dan methode pe-mahaman mereka ${ }^{200}$.

Prinsip ini terlalu kuat dan terlalu penting dalam Dinul Islam.Kepentingan dan keutamaannya didukung oleh dalil-dalil yang kuat dan jelas sekali.

${ }^{199}$ Team Ilmiah Eldasi, Ahlusunnah Waljamaah Metode Beragama Para Salaful Ummah,Pustaka al-Faruq. Hlm. 30-31.

${ }^{200}$ Ibid., 31-35. 


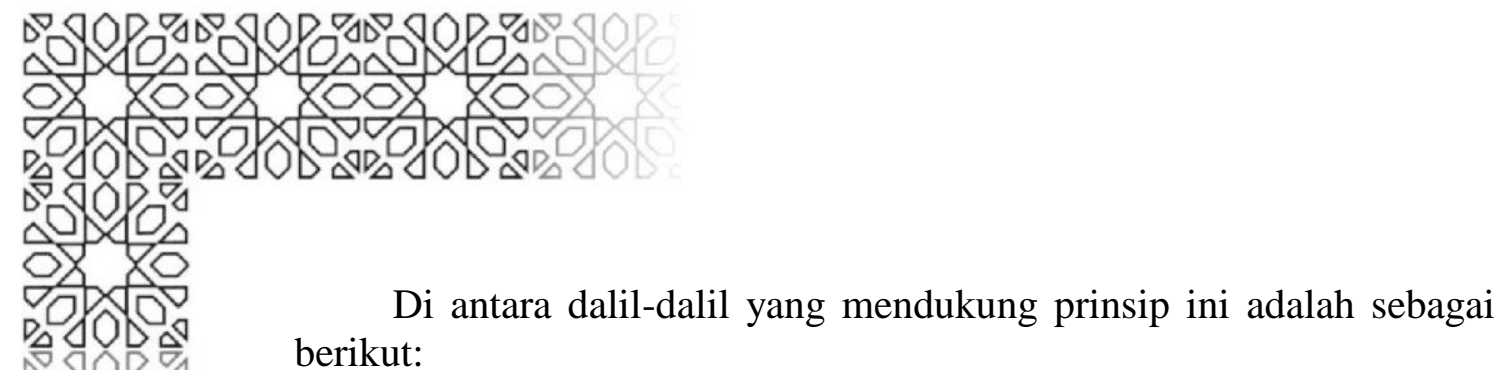
berikut:

(1) Sahabat telah dipuji Alloh Subhanahu wa Ta`ala di banyak ayat suci Al-Qur'an. Pujian yang diabadikan sepanjang masa dan tidak diberikan untuk orang-orang sesudah mereka.

Alloh Subhanahu wa Ta`ala berfirman:

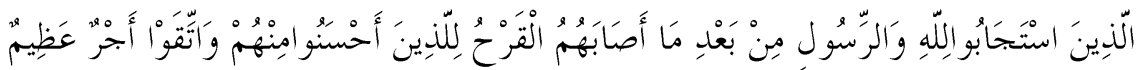

"(Yaitu) orang-orang yang menta'ati perintah Alloh dan Rosul-Nya sesudah mereka mendapat luka (dalam peperangan Uhud).Bagi orangorang yang berbuat kebaikan di antara mereka dan yang bertaqwa ada pahala yang besar".\{QS. Al Imran [3]: 172\}

(2) Sahabat telah diakui sebagai umat terbaik sepanjang umur dunia ini dan telah diridhoi Alloh Subhanahu wa Ta`ala.

Alloh Subhanahu wa Ta`ala berfirman:

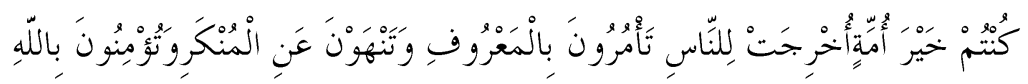

"Kalian adalah umat terbaik yang dilahirkan untuk manusia, menyuruh kepada yang ma'ruf dan mencegah dari yang munkar serta beriman kepada Alloh".\{QS. Ali 'Imron [3]: 110\}

(3) Manhaj Sahabat telah dijadikan ukuran standar untuk mengukur keimanan setiap orang. Siapa-siapa yang cocok keimanannya dengan keimanan sahabat maka mereka telah mendapat hidayah dan barangsiapa yang tidak demikian, serta me-nolak manhaj sahabat maka mereka telah sesat.

Alloh Subhanahu wa Ta`ala berfirman:

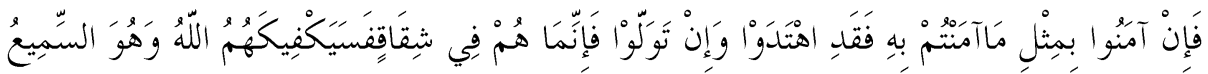

"Maka jika mereka beriman seperti apa yang kalian telah beriman kepadanya, sungguh mereka telah mendapat petunjuk dan jika mereka berpaling, sesungguhnya mereka berada dalam kesesatan. Maka Alloh akan me-melihara kalian dari mereka. Dan Dialah Yang Maha Mendengar lagi Maha Mengetahui".\{QS. Al Baqoroh [2]: 137\} 
d) Ahlussunnah wal Jama`ah menolak semua bentuk bid'ah, baik bid'ah amaliah, aqidah maupun manhajiyah ${ }^{201}$.

Semua bid'ah dalam agama adalah buruk dan sesat, tidak ada satu bid'ah pun yang hasanah.

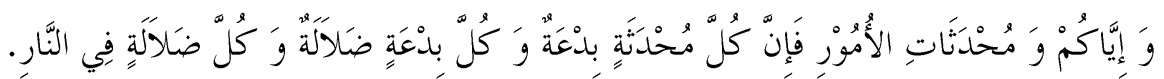

"Waspadalah kalian terhadap perkara-perkara baru (dalam dien), karena setiap perkara baru adalah bid`ah dan setiap bid`ah adalah sesat dan setiap kesesatan berada di api neraka".

e) Semua hadits sohih diterima sebagai dalil dan dasar untuk semua masalah termasuk masalah aqidah baik itu hadits mutawatir atau pun hadits ahad ${ }^{202}$.

As-Salafus sholeh tidak pernah membeda-bedakan antara hadits ahad dan hadits mutawatir, tetapi secara teknis ulama-ulama hadits di kemudian hari telah mengadakan pembagian yang demi-kian itu.Hadits ahad adalah hadits yang pada salah satu tingkatan perawinya mempunyai bi-langan yang tidak sampai derajat mutawatir.Ahlul bid'ah banyak menolak hadits-hadits ahadini se-bagai dalil untuk aqidah dengan alasanhadits ahad tidak sampai pada derajat yakin. Alasan ini tidak diterima olehAhlussunnah wal Jama`ah sejak zaman Rosululloh sampai akhir zaman. Alasan seperti ini dilahirkan oleh kaidah-kaidah filsafat.

f) Wahyu dari Alloh Subhanahu wa Ta’ala tidak ada yang bertentangan dengan akal yang bersih. ${ }^{203}$

g) Ahlussunnah beriman kepada semua khabar-khabar goib yang datang dari Alloh Subhanahu wa Ta ala melalui Al-Qur'an dan As Sunnah dan tidak mempercayai khabar goib apa pun dari selain keduanya. ${ }^{204}$

h) Al Iman terdiri dari empat unsur yaitu perkataan hati, perbuatan hati, perkataan lisan dan perbu-atan anggota badan. ${ }^{205}$

Perkatan hati adalah ilmu syar'i yang dipercayai oleh seseorang dan perbuatan hati adalah keadaan hati yang dilahirkan oleh perkataan

${ }^{201}$ Team Ilmiah Eldasi, Ahlusunnah Waljamaah Metode Beragama Para Salaful Ummah,Pustaka al-Faruq. Hlm. 30-31.

${ }^{202}$ Ibid., Hlm. 37.

${ }^{203}$ Ibid., Hlm. 39.

${ }^{204}$ Ibid., Hlm. 39.

${ }^{205}$ Ibid., Hlm. 42. 
hati seperti takut dan cinta kepada Alloh, cinta rosul, sahabatnya dan kaum muslimin, benci kepada kekufuran dan kuffar (orang-orang kafir), tawakal dan lain-lain-nya.Sedangkan perkataan lisan seperti syahadatain, istigfar, tasbih, da'wah dan lain-lain.Dan perbuatan anggota badan seperti sholat, shoum, haji, infaq dan lain-lain.Ketika perkataan hati dan perbuatan hati digabungkan, terkadang al-iman juga disebutkan sebagai aqidah, perkataan dan perbuatan.

Iman juga bisa berkurang dan bertambah.Ber-kurang dengan berkurangnya kapasitas unsur-unsurnya dan bertambah dengan bertambahnya kapasitas unsur-unsurnya atau berkurang dengan kema`siatan dan bertambah dengan keta`atan. Setiap unsur-unsur dari unsur-unsur iman disebut juga sebagai iman dan ketika salah satu unsurnya dari unsur-unsur tersebut tidak ada sama sekali atau bagian terdasar dari suatu unsur tidak ada atau ter jadinya perbuatan salah satu pembatal-pembatal iman, runtuhlah iman dengan seluruh unsur-unsurnya.

i) Ketika kufur Akbar terjadi pada salah satu unsur iman yang empat itu, maka keluarlah seseorang dari Islam. ${ }^{206}$

j) Seseorang yang bersyahadatain adalah Muslim sampai terbukti kekufurannya ${ }^{207}$. Rosululloh Shallallohu `alaihi wa sallam bersabda:

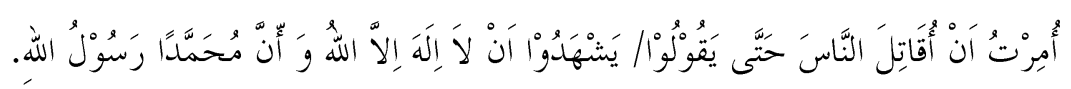

"Aku diperintahkan untuk memerangi manusia, hingga dia mengucapkan / bersyahadat bahwa tidak ada Ilah kecuali Alloh dan sesungguhnya Muhammad adalah utusan Alloh".

k) Tauhidulloh (Pengesaan Alloh) adalah dasar agama Islam yang terutama bahkan Islam se-luruhnya berdiri atas Tauhidulloh.

Barangsiapa yang melakukan kesyirikan atau mengaqidahkannya, lalu mati sebelum bertaubat, maka dia akan kekal di neraka jahannam dan tidak akan diampuni Alloh walaupun mempunyai amal sholeh sebesar bumi ini.

Alloh Subhanahu wa Ta`ala berfirman:

\footnotetext{
${ }^{206}$ Ibid., Hlm. 43.

${ }^{207}$ Ibid., Hlm. 43.
} 


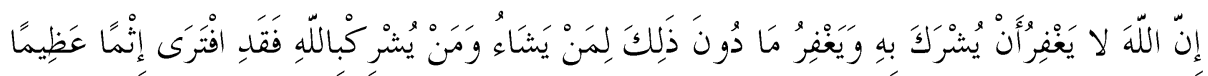

"Sesungguhnya Alloh tidak akan mengampuni dosa syirik, dan Dia mengampuni segala dosa selain (syirik) itu bagi siapa yang dikehendaki-Nya.Barangsiapa yang mempersekutukan Alloh, maka sungguh ia telah ber-buat dosa yang besar". \{Qs. An-Nisaa' [4]: 48\}

1) Ahlussunah beriman kepada nama-nama dan sifat-sifat Alloh yang dijelaskan di dalam Al-Qur'an dan Sunnah tanpa merubahrubahnya atau menolak sebagiannya atau menentukan hakikat-nya atau menyamakan dengan makhluk-Nya. Ahlussunah juga menyangkal semua sifat atas Alloh yang disangkal Alloh dan Rosul-Nya dan di waktu yang sama mengambil sikap diam terhadap sifat dan nama yang tidak ditetapkan atau pun disangkal oleh wahyu.

m) Penerapan hukum Alloh Subhanahu wa Ta`ala sebagai satu-satunya undang-undang yang me-mayungi kehidupan bermasyarakat dan bernegara adalah suatu kewajiban mutlaq yang besar.

Penyingkiran hukum-hukum Alloh Subhanahu wa Ta`ala seluruhnya atau sebagiannya dan meng-gantikannya dengan hukumhukum mahkluk ada-lah kufur akbar yang mengeluarkan pelakunya dari Islam. Penerapan hukum-hukum Alloh Subhanahu wa Ta`ala di bumi ini adalah bagian yang besar dari hak-hak uluhiyah.

Alloh Subhanahu wa Ta`ala berfirman:

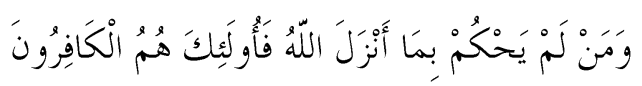

"Barangsiapa yang tidak berhukum pada apa-apa yang diturunkan Alloh, mereka itulah orang-orang kafir.’'\{Qs. Al Maidah [5] : 44\}

n) Ahlussunnah memberikan wala' (loyalitas) yang mutlak (sepenuhnya) kepada Alloh Subhanahu wa Ta`ala dan Rosul-Nya Shallallohu 'alaihi wa sallam. Memberikan wala' yang mutlak kepada kaum muslimin dalam jihad mereka melawan kuffar dan munafiqin.

o) Ahlussunnah beriman akan adanya malaikat dengan sifat-sifat dan nama-nama yang dijelas-kan di dalam Al Qur'an dan Hadits-hadits Rosululloh Shallallohu `alaihi wa sallam. 


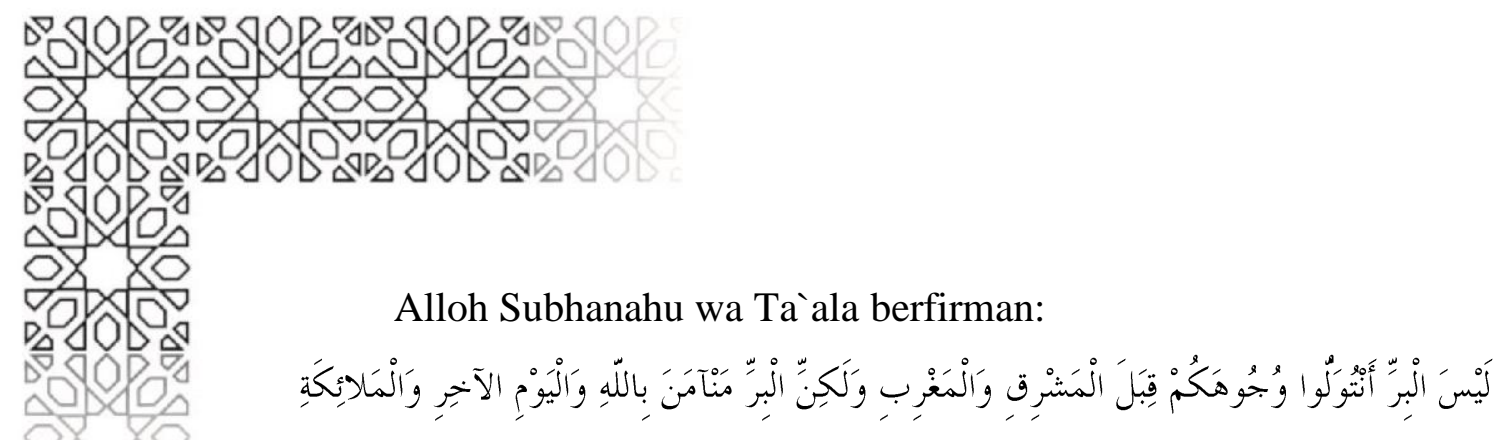

"Kebajikan itu bukanlah dengan memalingkan wajah-wajah kalian ke timur dan ke barat, tetapi kebajikan adalah keimanan kepada Alloh, hari akhir dan malaikat-malaikat...".\{QS. Al Baqoroh [2]: 177\}

p) Ahlussunnah beriman bahwasannya Alloh Subhanahu wa Ta`ala telah mengutus Rosul-rosul-Nya kepada setiap umat dengan Tauhid. Ahlussunnah pun bersaksi bahwa para Rosul yang mulia itu telah menyampaikan risalah Alloh Subhanahu wa Ta`ala dan menunaikan amanah mereka.

q) Muhammad Ibnu Abdillah adalah Rosul (utusan) Alloh Subhanahu wa Ta`ala terakhir dan tidak ada nabi dan rosul sesudahnya sampai hari kiamat.

r) Alloh Subhanahu wa Ta`ala telah menurunkan kitab-kitab-Nya yang tidak mengandung sedikit pun padanya kebatilan dan AlQur'an adalah kitab terakhir yang menjadi satu-satunya kitab panutan setelah kebangkitan Nabi Muhammad Shallallohu `alaihi wa sallam.

s) Alam Barzakh alam antara dunia dan akhirat adalah haq, pertanyaan Malaikat kepada ahlul kubur adalah haq. Azab dan ni'mat kubur adalah haq.

t) Yaumul Qiyamah pasti datang. Tiada keraguan tentangnya. Tak ada seorang mahkluk pun yang tahu tentang waktunya, hanya Alloh-lah yang mengetahuinya. Semua khabar dari Al-Qur'an dan Hadits shohih tentang hari ini adalah haq.

u) Ahlussunnah beriman kepada Qodarulloh, bah-wasanya seluruh yang baik maupun yang buruk hanya dari Alloh saja.

v) Ahlussunnah beriman pada wahyu (Kitab dan Sunnah) seluruhnya, tidak meninggalkan se-bagian dan menerima sebagiannya lagi. Selu-ruh wahyu harus diterima dan ditegakkan.

w) Ahlussunnah berprinsip menegakkan Amar Ma'ruf' Nahi Munkar 
x) Tidak ada seorangpun yang ma'sum selain Rosululloh Shallallohu ‘alaihi wa sallam. ${ }^{208}$

\section{Ahlussunnah Waljamaah Dalam Realita}

Pada umumnya semua kaum Muslimin adalahAhlussunnah wal Jama 'ah kecuali mereka yang telah berbid'ah pada salah satu dasar penting di dalam Islam atau mayoritas kehidupan keagamaannya terlumuribid'ah. Sedangkan orang Islam yang terkadang jatuh ke dalam suatu bid'ahatau mereka salah kira se-hingga mengira suatu bid'ah adalah sunnah maka orang-orang yang demikian bukanlah ahlul bid'ah.

Dalam hal yang berhubungan dengan bid'ah dan sunnah umat ini pada realitanya terbagi atas beberapa macam:
a. Alim Sunnah
b. Penuntut Ilmu sunnah
c. Jahil sunnah tetapi tidak jatuh pada bid'ah.

Macam ini sedikit sekali, karena kebanyakan jahil sunnah mudah ter-jatuh kepada bid'ah. Walaupun tidak jatuh, akan tetapi posisinya kritis sekali.

d. Jahil sunnah terkadang jatuh ke bid'ah.

Keempat macam di atas adalah bagian dari Ahlussunnah dan bukan dari Ahlul bid'ah.

e. Jahil sunnah tergenang dan berenang di bid'ah

Macam ini termasuk Ahlul bid'ah.

f. Ahlul bid'ah yang berilmu dan berbid'ah pada dasar-dasar penting Islam karena salah pengertian atau taqlid.

g. Ahlul bid'ah Zindiq yaitu orang-orang yang sengaja berjalan di atas bid'ah untuk mempermainkan agama.

Macam seperti ini adalah macam munafik yang sudah keluar dari Islam. Sayangnya macam seperti ini banyak yang menjadi pemimpin. $^{209}$

Berbicara Ahlussunnah dalam ranah Indonesia maka mayoritas

${ }^{208}$ Team Ilmiah Eldasi, Ahlusunnah Waljamaah Metode Beragama Para Salaful Ummah,Pustaka al-Faruq. HIm. 43-65.

${ }^{209}$ Team Ilmiah Eldasi, Ahlusunnah Waljamaah Metode Beragama Para Salaful Ummah,Pustaka al-Faruq. HIm. 66-68. 
mereka adalah kaum muslimin yang bermanhajkan Ahlussunnah waljamaah. Hal ini berdasarkan salah satunya kepada pengakuan yang mereka sampaikan.Walaupun pada gilirannya pengakuan tersebut harus dibuktikan dengan timbangan prinsip-prisip Ahlussunnah diatas.

Di kebanyakan perguruan tinggi di Indonesia manhaj pluralisme produk orientalis-lah yang diajar-kan. Manhaj ini menggambarkan bahwa tidak ada standar pemahaman dalam Islam, Islam boleh saja dipahami dengan metode-metode pemahaman yang berbeda-beda. Dengan demi-kian menurut manhaj ini semua manhaj firoq bisa benar dan bisa salah. Juga manhaj Ahlussunnah pun bisa benar dan bisa salah, karena menurut mereka Islam bisa diterima dalam bentuk lebih dari satu versi. Tujuan manhaj ini adalah mengaburkan yang haq dari yang bathil. Kaum orientalis bukannya tidak mengetahui bahwa standar pemahaman Ahlussunnah terhadap Al-Qur'an dan Sunnah yaitu pemahaman sahabat telah didu-kung oleh dalil-dalil Qur'an dan Hadits yang jelas dan kuat sekali serta tiada keraguan padanya. Akan tetapi memang sudah menjadi misi dan tugas mereka sebagai pengikut Iblis untuk merusak Islam dan kaum Muslimin serta memproduksi syubhat seputar Islam sebanyak-banyaknya. ${ }^{210}$

\section{Kesimpulan}

Dari penjabaran tentang konsepsi Ahlussunnah Waljamaah dalam tinjauan hadits Iftirāq, dapat disimpulkan ke dalam beberapa poin berikut:

1. Hadits-hadits iftirāq secara redaksional yang valid jalur periwayatannya adalah yang menyebutkan 73 golongan, satu di surga sedangkan yang lainnya di neraka.

2. Konsepsi Ahlussunnah Waljamaah yang terangkum dalam definisi dan prinsip-prinsip dasarnya adalah sarana utama untuk mengukur seseorang itu disebut sebagai bagian daripada Ahlussunnah Waljamaah atau bukan.

3. Secara global antara idealita konsepsi Ahlussunnah Waljamaah dengan realita kaum muslimin yang menganutnya sudah banyak kesamaan, walaupun harus terus dikembangkan lagi supaya dapat mengamalkan konsepsi ahlussunnah yang ideal dengan baik dan benar.

\footnotetext{
${ }^{210}$ Ibid., Hlm. 67-68.
} 


\section{DAFTAR PUSTAKA}

Al Qur'an dan Terjemahnya.

'Alā, Muhammad 'Abdurrahmān ibn 'Abdurrahīm al-Mubārakfūrī Abū al-, Tuhfat al-Ahwadzī Bisyarh Jāmi' al-Tirmidzī, Dar al-Kutub al-'Ilmiyah: Beirut

A.W. Munawwir, Kamus al-Munawwir Arab-Indonesia Terlengkap, Surabaya: Pustaka Progressif, 1997 M

Baidhāwī, Al-Qādhī Nāshir al-Dīn 'Abdullāh ibn 'Umar al-, Tuhfat alAbrār Syarh Mashābih al-Sunnah, Tahqīq: Tim Khusus diketuai Nuruddin Thalib, Wazaratul Awqaf Wa al-Syuun alIslamiyah: Kuwait, 2012

Dimasyqī, Abū al-Fidā Ismā'îl ibn 'Umar ibn Katsīr al-Qurasȳ̄ al-, Tafsìr al-Qur'ān al-'Ażìm, Tahqīq: Sāmī ibn Muhammad Salāmah, Dar Thaibah.

Fauzān, Shāliḥ al-, Syarh al-'Aqīdah al-Wāsithiah, Kairo: Dār al'Aqīdah $1426 \mathrm{H} / 2005 \mathrm{M}$.

Furaih, Māzin ibn 'Abd al-Karīm al-, al-Rāid Durūs F̄̄ al-Tarbiyah Wa al-Da'wah, Dar al-Andalus al-Khadhrā: Jeddah.

Ibn Taimiyah, Majmu'at al-Fatawa, Riyadh: Maktabah al-'Ubaikan 1419 H/ 1999 M.

Muhammad ibn Yazīd Abū 'Abdillāh al-Quzwain̄̄, Sunan Ibn Mājah, Tahquīq:Muhammad Fuād 'Abd al-Bāqī, Dar al-Fikr: Beirut.

Sa'd̄̄, 'Abd al-Rahmān ibn Nāshir al-, Taisìr al-Karīm al-Rahmān F̄̄ Tafsìr Kalām al-Mannān, Tahqīq: 'Abd al-Rahmān ibn Mu'allā al-Luwaihiq, Muassasah al-Risalah.

Sijistānī, Abū Dāwūd Sulaimān ibn al-Asy'ats al-, Sunan Abī Dāwūd, Dar al-Kitab al-'Arabi: Beirut.

Team Ilmiah Eldasi, Ahlusunnah Waljamaah Metode Beragama Para Salaful Ummah,Pustaka al-Faruq.

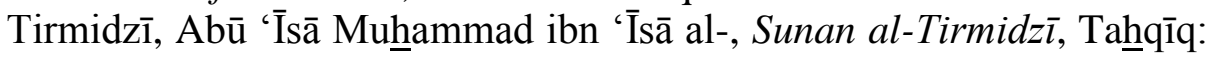

Basysyār 'Awād Ma'rūf, Dar al-Gharb al-Islami: Beirut.

http://www.ahlalhdeeth.com/vb/showthread.php?t=2710

https://islamqa.info/ar/225230

http://www.visimuslim.net/2014/09/memahami-hadits-terbaginya-

kaum-muslimin-menjadi-73-golongan.html 